\title{
KATEGORIA STATUSU METODOLOGICZNEGO NAUKI
}

\section{Uwagi wprowadzające}

Celem artykułu jest utrwalenie i doprecyzowanie znaczenia terminu "status metodologiczny nauki", a tym samym wzmocnienie samoświadomości metodologicznej. Prezentowane rozważania służą autorefleksji, gdyż omówione tu kategorie stosują się również do metodologii i filozofii nauki. Pojęcie statusu metodologicznego jest najogólniejszą kategoria, pozwalającą adekwatnie scharakteryzować od strony formalnej naukę w ogóle i poszczególne dyscypliny naukowe. Chociaż używane przez wielu, kiedy zwracają oni uwagę na wyznaczniki statusu nauki, nie doczekało się dokładniejszego określenia, doprecyzowującego jego znaczenie oraz sens konstytuujących je wyznaczników. W elementarnym i mającym służyć dydaktyce tekście chciałabym ten brak nadrobić.

\section{Pojęcie i termin "status"}

Termin "status" jest wyrażeniem bogatym znaczeniowo, używanym w odniesieniu do stanu rzeczy/rzeczywistości lub nazwy czegoś w określonym kontekście sytuacyjnym, społecznym, prawnym, zawodowym itp. (Status). W branym tu pod uwagę sensie znaczy on: położenie, pozycję, stan, stan rzeczy, sytuację, usytuowanie, kondycję, zawartość czegoś a także autorytet, renomę czy rangę. W zależności od kontekstu status czegoś może być różny, dlatego najbardziej informatywne i precyzyjne jest mówienie o statusie z przydawką np. o statusie metodologicznym nauki, a nie o jej statusie po prostu. Status nauki może być bowiem różnie rozumiany - jako metodologiczny, ontologiczny, epistemologiczny, aksjologiczny, społeczny, instytucjonalny, ekonomiczny, polityczny itp.

Metodologiczny status danej nauki może być rozważany w odniesieniu do dwóch podstawowych sposobów jej rozumienia: nauki uprawianej badawczo (badania) i nauki uprawianej dydaktycznie (kształcenie, 
dydaktyka). Pierwszorzędnie chodzi o status metodologiczny nauki uprawianej badawczo, gdzie celem jest uzyskanie nowej wiedzy, nowych, oryginalnych, dotychczas nieznanych, twórczych rezultatów. Do tak rozumianej nauki odnoszę dalsze uwagi.

Główne konteksty pojawiania się i wykorzystania pojęcia statusu metodologicznego nauki to:

1) porządkowanie (typologia) nauk i wskazania jej kryteriów;

2) określenie metodologicznej specyfiki poszczególnych nauk lub typów nauk („,osobliwości nauk”);

3) odróżnianie poszczególnych nauk lub typów nauk;

4) problematyka metodologicznej autonomii pewnej nauki;

5) problematyka unifikacji nauk (zagadnienie o proweniencji pozytywistycznej);

6) modne dzisiaj rozumienie interdyscyplinarności i integracji nauki.

\section{Kamińskiego ujęcie nauki i tradycja Szkoły Lwowsko-Warszawskiej}

Punktem odniesienia dla przedstawienia sposobu rozumienia kategorii statusu metodologicznego nauki jest tradycja metodologiczna zapoczątkowana w KUL przez ks. prof. Stanisława Kamińskiego. Stanowi ona część tradycji Lubelskiej Szkoły Filozoficznej, którą autor przedstawił w pracy Nauka i metoda. Pojęcie nauki i klasyfikacja nauk ([1961] 1992). W swych badaniach Kamiński nawiązuje tu teoretycznie do pism metodologów i teoretyków nauki Szkoły Lwowsko-Warszawskiej, zwłaszcza Tadeusza Kotarbińskiego, Tadeusza Czeżowskiego oraz Kazimierza Ajdukiewicza, rozwijając równocześnie twórczo własne, chociaż bliskie teoretycznie wymienionym autorom pomysły. Chodzi zwłaszcza o elementy i kryteria charakterystyki poszczególnych nauk i typów nauk przez Kotarbińskiego, wyłożone w Elementach teorii poznania, logiki formalnej i metodologii nauk $(1929,1990)$ a także w pracach Czeżowskiego (m.in. 1958). Elementy te wykorzystane są jako oś konstrukcyjna rozdziału Determinacja natury nauki w książce Nauka i metoda (Kamiński 1992, s. 183-248). Po pewnych uzupełnieniach i modyfikacjach można je zebrać i przedstawić w postaci kategorii statusu metodologicznego nauki. Idee Kamińskiego są zbieżne z późniejszymi w stosunku do Nauki i metody (1961) tekstami Ajdukiewicza, głównie z fragmentami Logiki pragmatycznej $(1965,1975)^{1}$

${ }^{1} \mathrm{~Np}$. „A więc 1) wyróżnienie typów czynności wykonywanych przy uprawianiu nauki oraz ich analiza, doprowadzająca do definicji zdających sprawę z tego, na czym czynności te polegaja, 2) opis procedury naukowej (w ogólnych zarysach) stosowanej w różnych naukach, 3) dopatrzenie się zadań, do których wykonania, świadomie lub nie- 
(zwłaszcza rozdział Metodologiczne typy nauk) oraz artykułem Metodologia i metanauka (1985) oraz tekstami Czeżowskiego (1965; 1967).

W Nauce i metodzie (1992, s. 103) Kamiński raz tylko używa terminu "status metodologiczny nauki" w odniesieniu do nauk humanistycznych w kontekście poglądów Johna Stuarta Milla. Również w pismach przedstawicieli Szkoły Lwowsko-Warszawskiej termin ten pojawia się rzadko. Zarówno jednak u Kamińskiego, jak i w Szkole Lwowsko-Warszawskiej istnieje pojęcie statusu metodologicznego nauki (rozumiane jako znaczenie terminu) w postaci rozproszonych, rozrzuconych po różnych tekstach jego elementów (determinantów), głównie charakterystyki nauk z punktu widzenia ich przedmiotu badań, metody, zadań, stawianych zagadnień, genezy itp. ${ }^{2}$ Zbieram te elementy w całość w postaci kategorii statusu metodologicznego nauki. Wypracowywanie takich ogólnych pojęć do opisu i analizy nauki (tego czym jest, co się w niej robi i co uzyskuje) pozostaje zasadnym zadaniem metodologii nauk.

\section{Wyznaczniki statusu metodologicznego nauki}

Kategoria statusu metodologicznego nauki jest ważna przy determinacji natury nauki (Kamiński 1992, s. 184-248), tzn. jej określeniu (definiowaniu), próbie rozwiązania problemu demarkacji, tj. odróżnienia nauki od tego, co nią nie jest, oraz problematyce autonomii nauki, podejmowanej zarówno w postaci zagadnienia autonomii nauki jako dziedziny kultury wobec innych jej dziedzin (np. gospodarki czy polityki),

świadomie, zdążają uczeni specjaliści różnych nauk, i oparta na tym kodyfikacja norm poprawnego postępowania w naukach - oto (trzy główne zadania tego działu metodologii, którego przedmiotem badań jest nauka pojęta jako rzemiosło uczonych, tj. nauk jako czynność. Ten dział metodologii nazwiemy metodologią pragmatyczną od greckiego $\pi \rho \alpha ́ \gamma \mu \alpha$, czytaj „pragma”, co znaczy to samo, co polskie "czyn”)” (Ajdukiewicz 1965, s. 175) oraz „Nie można bowiem mówić o zabiegach poznawczych, nie mówiąc o zdaniach lub konstrukcjach złożonych ze zdań, w których wyniki tych zabiegów są sformułowane" (Ajdukiewicz 1965, s. 176).

${ }^{2} \mathrm{~Np}$.: ,Zależnie od celu klasyfikacji nauk można wybierać rozmaite zasady podziału: 1. według przedmiotu (np. zoologia - o zwierzętach, botanika - o roślinach), 2. według metody (np. matematyka - dedukcyjna, psychologia - indukcyjna), 3. według tego, pod jakim względem przedmioty są badane (np. chemia bada ciała pod względem ich budowy drobinowej, mechanika - pod względem ich własności ruchowych), 4. według charakteru logicznego tez, do których dana nauka dąży (np. fizyka dąży do praw następstwa lub współbytności zdarzeń, historia - do opisu i wytłumaczenia toku dziejów), 5. według władz umysłowych, przede wszystkim dla danej nauki potrzebnych (np. jedne nauki więcej wymagają pamięci, inne - więcej pomysłowości w rozumowaniu, inne znowu - więcej spostrzegawczości itp.)" (Kotarbiński 1990, s. 335). 
jak i w postaci autonomii pewnej nauki (np. pedagogiki) wobec innych nauk (np. psychologii czy socjologii) ${ }^{3}$. Ustalenie tych zależności napotyka liczne trudności w związku z wieloaspektowością i zmiennością nauki. Wyodrębnienia w ramach kultury i poznania tego, co z metodologicznego punktu widzenia nazywa się nauką można dokonywać na wiele sposobów. Kategoria statusu metodologicznego nauki pozwala w sposób ogólny i nieredukcjonistyczny na metodologiczną charakterystykę natury nauki oraz dostarczenie formalnego schematu jej analizy. Ujmuje ona to, dzięki czemu z metodologicznego punktu widzenia nauka jako całość uchodzi za naukę oraz pozwala dobrze charakteryzować poszczególne typy nauk, poszczególne nauki (dyscypliny naukowe) oraz projekty badawcze. Przez metodologiczny punkt widzenia (właściwy metodologii nauk) rozumiem takie podejście do nauki, w którym charakterystycznym aspektem jej ujmowania jest aspekt poznawczy (epistemiczny), tj. nauka rozumiana jako działalność poznawcza oraz charakteryzowana nie pod względem treściowym, lecz pod względem formalnym. Formalna charakterystyka nauki obejmuje metanaukowe (metaprzedmiotowe), strukturalne elementy determinacji nauki jako poznania, np. kategorie problemu czy metody badawczej, służące do kategoryzowania „wnętrza" nauki.

O statusie metodologicznym pewnej nauki decydująjego determinanty, czyli wyznaczniki natury nauki. Zalicza się do nich: przedmiot nauki/ badań, problematykę nauki/badań, cel (funkcje) nauki/badań, metodę nauki/badań, strukturę uzyskanych rezultatów badań (wiedzy), język nauki oraz genezę i dynamikę (historię) nauki/badańt. Tworzą one schemat formalnej charakterystyki nauki i dostarczają kryteriów porządkujących, wykorzystywanych w różnych badaniach i opisach nauki. Mają dwoisty charakter: mogą służyć zarówno jako kryteria różnicowania nauk, jak i kryteria ich integracji (Kamiński 1992, s. 277-279). Kolejno wprowadzam i omawiam wstępnie pojęcia służące jako wyznaczniki statusu metodologicznego nauki.

${ }^{3}$ Jako przykład por. pedagogikę jako naukę, którą określa się jako autonomiczna, gdyż ma własny przedmiot, cel (funkcje), metodę, strukturę i genezę, problematykę, język (Bronk 2003).

4 „Naukę można określić rozmaicie: czy to wskazując j przedmiot formalny i cel, czy to wyróżniając jej problematykę, czy wreszcie opisując jej strukturę logiczną i język. Nie będą to jednak znamiona najbardziej diagnostyczne. Istotnym sprawdzianem naukowości, posiadającym przy tym ogromne walory dydaktyczne i wielostronną użyteczność, okazuje się metoda uprawiania nauki" (Kamiński 1992, s. 200). 


\section{Przedmiot badań}

Pierwszorzędnym wyznacznikiem metodologicznego statusu nauki jest przedmiot nauki, tj. to, co dana nauka bada ${ }^{5}$. Wyznaczanie obszaru (zakresu) rzeczywistości, którym zajmuje się określona nauka (badanie), pozostaje w wielorakich związkach z decyzjami dotyczącymi pozostałych determinantów natury nauki, w szczególności problematyki badawczej, celu i metody badań. Przedmiot nauki stanowi odpowiednik dla wyznacznika, jakim jest język nauki, w postaci aparatury pojęciowej (słownika) danej nauki. Określenie przedmiotu nauki uwarunkowane jest poprzez założenia ontologiczne, epistemologiczne i metodologiczne, wyznaczające zakres tego, co uważa się za możliwe do badania przez naukę (jej metodami), i tego, co przyjmuje się za część (realnej, istniejącej) rzeczywistości ${ }^{6}$. Ze względu na wymienione założenia można wyróżnić dwa typy stanowisk odnośnie do przedmiotu nauki: monistyczne i pluralistyczne. Dyskutując z monistycznym, redukcjonistycznym i pozytywistycznym ujęciem przedmiotu nauki (materialistycznym monizmem) i ograniczeniem go do tzw. faktów, Kamiński opowiada się za pluralistyczną tezą o wielości i różnorodności przedmiotów nauki. Przyznaje, że uznanie jednego rodzaju rzeczywistości ułatwia zbudowanie jednolitej teorii nauki i sformułowanie kryteriów naukowości wspólnych dla całej nauki, a tym samym jej unifikację, uważa jednak, że monistyczne traktowanie rzeczywistości zubaża poznanie ludzkie „nie tyle może wyłączając z obszaru badań naukowych wiele faktów, ile ograniczając możliwość wielokierunkowej interpretacji tych faktów" (Kamiński 1992, przypis 2, s. 186).

Poręcznymi kategoriami przy charakterystyce przedmiotu nauki wydają się pary pojęć: przedmiot materialny - przedmiot formalny oraz przedmiot badania w punkcie wyjścia - przedmiot w punkcie dojścia. Znane kiedyś dobrze scholastyce odróżnienie przedmiotu materialnego i formalnego nie jest dziś zbyt często używane, chociaż trafnie oddaje charakter nauki, a zwłaszcza procesu badawczego, tzn. jego nieuchronną wycinkowość i aspektywność. Przedmiot materialny to przedmiot dany

${ }^{5}$ O przedmiocie nauki por. (Kamiński 1992, s. 184-192).

6 "Gdy bierze się pod uwagę system naukowy, to przedmiotem jego będzie po prostu wszystko, co jest denotowane przez wyrażenia stałe (oraz reprezentowane przez zmienne) występujące $w$ tezach tego systemu. Bezpośrednim przedmiotem teorii naukowej jest wyidealizowany w jakimś aspekcie model pewnej klasy przedmiotów konkretnych (wedle jednych) albo układ domniemanych przedmiotów i stanów rzeczy (wedle innych). Ale zdarzenia, stany rzeczy i struktury (substancjalne albo nie) są raczej pochodnym obiektem nauki. Charakterystyka tego ostatniego związana jest ściśle z teorią filozoficzną. I w tym punkcie najbardziej różnią się determinacje przedmiotu nauki" (Kamiński 1992, s. 187-188). 
do badania w całym swoim uposażeniu i bogactwie aspektów, przedmiot formalny to fragment (wycinek) przedmiotu materialnego, ujęty w określonym aspekcie (z danego punktu widzenia) ${ }^{7}$. Uwzględnienie różnicy między przedmiotem materialnym a formalnym pozwala dobrze uświadomić sobie, że każde badanie (poznanie) ma charakter wybiórczy, tzn. że ten sam przedmiot może być ujęty $\mathrm{w}$ procesie badawczym $\mathrm{w}$ różnych aspektach i na różne sposoby. Przykładowo, jeśli przyjąć, że przedmiotem materialnym pedagogiki jest wychowanie, to może on być badany w różnych aspektach, np. celów wychowania, metod wychowawczych, kontekstu kulturowego wychowania itp. W ten sposób dochodzi do powstania różnych przedmiotów formalnych. Co więcej, każdy przedmiot formalny może być ponownie potraktowany jako całość dana do zbadania, dająca się kolejno różnicować na coraz węziej pojęte przedmioty formalne. Na takim różnicowaniu i kawałkowaniu przedmiotu badań polega proces specjalizacji badań, znany dobrze zarówno wcześniejszej nauce, jak i nauce współczesnej (Walczak 2016, s. 499).

Kolejne odróżnienie przedmiotu badań w punkcie wyjścia i punkcie dojścia pozwala zwrócić uwagę na to, że czymś innym jest wstępne rozumienie przedmiotu nauki przyjmowane $\mathrm{w}$ punkcie wyjścia badania, a czymś innym jego rozumienie po ich przeprowadzeniu $\mathrm{w}$ punkcie dojścia, kiedy w trakcie procesu poznawczego dochodzi do przyrostu wiedzy. Z jednej strony badacz musi dysponować jakimś wstępnym pojęciem, intuicyjnym rozumieniem przedmiotu badania w postaci wstępnych założeń lub definicji przyjętych w punkcie wyjścia. Jest to nieodzowne, żeby odróżnić i odgraniczyć to, co badać a czego nie badać. Z drugiej taka wstępna determinacja przedmiotu badań przesądza poniekąd o uzyskanych wynikach. Niejednokrotnie w trakcie badania ${ }^{8}$ może się okazać, że trzeba będzie zmienić wstępne rozumienie ich przedmiotu poprzez modyfikację wstępnych definicji lub przyjętych założeń.

\section{Problematyka badawcza}

Przyjmując, że wstępnym, ukierunkowującym proces badawczy czynnikiem (etapem) metody naukowej jest stawianie problemów (pytań)", a cały proces badawczy daje się potraktować jako proces rozwiązywania

7 (Kamiński 1992, s. 187-188) oraz hasło Przedmiot w: (Podsiad, Więckowski 1983, kol. 302-303).

8 "Badanie” rozumiem szeroko jako czynności mające prowadzić do rezultatu w postaci wiedzy.

${ }^{9}$ Na temat pytań w nauce por. (Brożek 2007, s. 181-190). 
problemu, problematyka badawcza stanowi istotny wyznacznik statusu metodologicznego nauki (badań) (Kamiński 1992, s. 203) ${ }^{10}$.

Problem badawczy może być rozumiany różnie, jednak z punktu widzenia przydatności do opisu metody (procesu badawczego) dobrym sposobem jego charakteryzowania jest traktowanie go jako znaczenia (sensu) pytania, a procesu poszukiwania rozwiązania problemu- jako procesu poszukiwania odpowiedzi na zadane pytanie/pytania ${ }^{11}$. Pytanie jest wówczas rozumiane jako językowe sformułowanie pewnego problemu. W tym ujęciu przez problematykę (danej) nauki (badań) można rozumieć zbiór pytań, jakie stawia się w jej ramach i na jakie próbuje ona odpowiedzieć. Składa się na nią główny problem badawczy, którego rozwiązania podejmuje się pojedynczy naukowiec lub zespół badawczy, oraz szereg problemów szczegółowych, których postawienie i rozwiązanie potrzebne jest do rozwiązania problemu głównego. Ich sformułowanie w postaci pytań, wyraźne wyliczenie, uporządkowanie, a następnie hierarchizacja jest dobrym narzędziem badawczym, umożliwiającym planowanie i kontrolę procesu badawczego. Odpowiedzią na główne pytanie badawcze jest teza (hipoteza) badawcza, którą badacz stawia i której prawdziwość (wartość poznawczą) powinien uzasadnić.

Językowe sformułowanie problemu w postaci pytania jest narzędziem wyboru i precyzowania przedmiotu i kierunku badań. Pozwala doprecyzować cel badań, czyli to, co chce się poznawczo osiągnąć i do czego się dąży, a poniekąd wyznacza także metodę badawcza, gdyż wstępna znajomość tego, czego szukamy, warunkuje wyznaczenie sposobu postępowania $\mathrm{w}$ dążeniu do celu. Użyta $w$ pytaniu partykuła pytajna wyznacza zakres niewiadomej pytania i umiejscawia to, czego się szuka, w kontekście tego, co już jest znane, wiedzy/założeń zawartych w danej pytania. Rekonstrukcja na podstawie danej pytania (datum quaestionis) jego założeń i wyartykułowanie ich w postaci zdań pozwala je poddać ocenie poznawczej (w kategoriach prawdy/fałszu lub innych kategoriach poznawczych). Jest to szczególnie ważne wówczas, kiedy pewnego problemu nie udaje się rozwiązać lub są z tym zasadnicze trudności, co pozwala sprawdzić, czy czasami nie są za nie odpowiedzialne fałszywe założenia pytania (Walczak 2016, s. 501).

${ }^{10}$ Kamiński nie rozwijał szczególnie wątku problematyki badawczej jako jednego z determinantów natury nauki ani czynnika integrującego lub unifikującego nauki, natomiast w jego wykładzie z ogólnej metodologii nauk logika pytań zajmowała istotne miejsce, a stawianie pytań było zaliczane do najbardziej elementarnych czynności poznawczych. Obecność tej problematyki dokumentują wykłady z OMN prowadzone na bazie wykładu Kamińskiego przez A. Bronka, por. (Bronk 2001), a także Z. Hajduka (Hajduk 2007, s. 57-59).

11 O znaczeniu stawiania problemów w badaniach por. (Walczak 2016). 


\section{Cel badawczy}

Ważnym determinantem statusu metodologicznego nauki jest cel badawczy ${ }^{12}$, rozumiany jako to, co chce się prowadząc badania (cel zamierzony) osiągnąć, lub to, co się (faktycznie) osiąga (cel osiągnięty). W przypadku celu poznania naukowego odróżnia się:

1) motywy (pobudki), skłaniające naukowca do zdobywania wiedzy naukowej (cel podmiotowy);

2) rezultat przedmiotowy (finis operis, tj. cel działania), do jakiego zmierza lub powinno zmierzać postępowanie badawcze (cel przedmiotowy), bądź wreszcie

3) to, czemu ostatecznie ma służyć poznanie naukowe, czyli funkcje, które nauka pełni w ludzkim życiu w postaci wykorzystania rezultatów naukowych (owoce nauki).

Chociaż zróżnicowane, cele te wiążą się ściśle ze sobą, a czasem stanowią nawet ten sam złożony cel, rozpatrywany z różnych punktów widzenia (Kamiński 1992, s. 192, 198). Przy metodologicznym ujęciu nauki celem centralnym okazuje się cel przedmiotowy, nazywany też wewnętrznym lub teoretycznym. Cel przedmiotowy rozumiany stanowi immanentny cel nauki traktowanej jako sposób uzyskiwania wiedzy o świecie.

Wśród celów przedmiotowych nauki wymieniane są:

1) opis naukowy jako odpowiedź na pytanie o to, jak przebiegają dane zjawiska/procesy oraz jakie mają cechy (uchodzi za wstępną fazę $\mathrm{w}$ uprawianiu nauki $\mathrm{i}^{13}$;

2) wyjaśnianie i/lub przewidywanie (głównie w naukach przyrodniczych lub społecznych), szukające odpowiedzi na pytanie typu dlaczego lub pytania pokrewne; widziane jest jako ostateczny cel nauki, kiedy przybiera dojrzałą postać teorii naukowej (jako ideał systematyzacji wiedzy naukowej);

3) interpretacja (humanistyczna), specyficzna dla nauk humanistycznych, traktowana jako odpowiednik wyjaśniania w naukach przyrodniczych lub społecznych;

4) ocena (wartościowanie, ewaluacja) zjawisk, zwłaszcza kulturowych, projektów rzeczywistości lub działania powstające w odpowiedzi na pytania: czy i jaką coś ma wartość;

5) normowanie pewnego fragmentu rzeczywistości przez formułowanie reguł działania w odpowiedzi na pytanie o to, jak coś być powinno lub jak należy postępować;

${ }^{12} \mathrm{Na}$ temat celu nauki jako jednego z głównych determinantów jej natury por. (Kamiński 1992, s. 192-200). Problematykę celu nauki w ujęciu Kamińskiego rozwijam w artykule (Walczak 2011).

13 Por. (Bronk, Majdański 1995). 
6) uzasadnianie tez, ocen lub norm jako cel wspierający pozostałe cele.

Wymienione cele wzajemnie się warunkują: nie dochodzi się do kolejnych celów, zanim nie zostaną zrealizowane cele wcześniejsze (Kamiński 1992, s. 198). Uznanie czwartego i piątego celu za poznawczy cel nauki zdaje się uzasadnione analizą swoistości metodologicznej nauk humanistycznych, stwierdzającą w nich faktyczną obecność wartościowania i normowania jako celów badania ${ }^{14}$.

\section{Metoda badawcza}

Tradycyjnie za najważniejszy determinant natury nauki uważana jest metoda badania ${ }^{15}$. Jej wskazanie jest odpowiedzią na pytanie, jak w ramach danej nauki prowadzić lub powinno się prowadzić badania. Mimo wielu trudności związanych z jej pojęciem i różnorodnością realizacji $\mathrm{w}$ poszczególnych naukach i typach nauk ${ }^{16}$ metoda naukowa pozostaje jednym z głównych czynników charakteryzujących naukę $\mathrm{w}$ ogólności i poszczególne badania naukowe, także interdyscyplinarne ${ }^{17}$. Stanowi postać, jaką przybierają działania (czynności) badawcze, czyni je działaniami planowymi, uporządkowanymi, świadomie wykonywanymi (samoświadomość metodologiczna) i powtarzalnymi (systematycznymi). Tradycyjnie przypisywano jej udoskonalanie wykonywanych czynności poprzez czynienie ich bardziej skutecznymi i ekonomicznymi (Kotarbiński 1990a). Metoda naukowa dostarcza wzorca postępowania naukowego, ale nie oznacza to, że jest on sztywny, raz na zawsze określony czy z konieczności wspólny dla wszystkich nauk.

Jako sposób rozwiązywania problemów (teoretycznych lub praktycznych) można ją rozumieć czynnościowo (jako uporządkowany zbiór czynności i środków, na których polega uprawiania nauki) lub regułowo (jako zbiór reguł wskazujących, jak i w jakim porządku te czynności wykonywać), a niekiedy także jako „zespół założeń przyjętych jako ramy lub wytyczne badania (np. gdy determinują przedmiot formalny i cel badań)" (Kamiński 1992, s. 202).

Na metodę naukową składają się elementarne czynności, mające różne realizacje i tworzące różnorodne konfiguracje w ramach poszczególnych

14 Współczesna filozofia nauki dostrzega i akceptuje aksjologiczny i normatywny wymiaru nauki, por. (Lekka-Kowalik 2008).

15 O metodzie jako podstawowym determinancie natury nauki por. (Kamiński 1992, s. 200-214).

16 Por. (Bronk 2006; Sankey 2014; Bronk, Walczak 2019).

17 Np. (Repko 2008, s. 200-212). 
typów nauk, dyscyplin naukowych i badań interdyscyplinarnych. Zalicza się do nich:

1) postawienie problemu (pytania);

2) gromadzenie materiału potrzebnego do rozwiązania problemu (zebranie danych empirycznych, analiza danych założeń proble$\mathrm{mu}$, zebranie źródeł historycznych itp.);

3) interpretację materiału, która pozwala hipotetycznie (i rozstrzygalnie) rozwiązać problem (np. polegającą na wykryciu ogólnej prawidłowości, wysunięciu hipotezy, zbudowaniu modelu, uzasadnieniu zdania: twierdzenia, oceny lub normy, albo zaprojektowaniu konstrukcji: jakiegoś przedmiotu lub operacji);

4) rozstrzyganie o wartości proponowanego rozwiązania/wyjaśnienia (w szerokim tego ostatniego słowa znaczeniu) albo uzasadnienia odkrytej tezy, albo planu konstrukcji (krytyczna analiza logiczna rozwiązania lub testowanie/sprawdzanie empiryczne: weryfikacja, falsyfikacja) i przyjęcie najbardziej wartościowego rozwiązania problemu;

5) budowanie teorii obejmującej swym wyjaśnieniem pewną jednolitą dziedzinę.

Przestawione czynności są zwykle wykonywane cyklicznie (Kamiński 1992, s. 203-205).

\section{Struktura wiedzy naukowej}

Za formalny determinant statusu metodologicznego nauki uważa się także strukturę międzyzdaniową wiedzy naukowej w postaci struktury logicznej, którą przybierają rezultaty badań naukowych (Kamiński 1992, s. 214-225 $)^{18}$. Na strukturę czegokolwiek składają się jego elementy (podstawowe składowe) i zachodzące między nimi relacje. W przypadku nauki elementami tymi są przede wszystkim zdania (twierdzenia, hipotezy, prawa naukowe) oraz terminy (pojęcia). Wyróżnionym rodzajem związków przy charakterystyce struktury nauki są związki uzasadniające (logiczne, inferencyjne) pomiędzy zdaniami składającymi się na teorię naukową. $\mathrm{W}$ metodologii nauk i filozofii nauki w sensie ścisłym termin "teoria" odnoszony jest do nauk formalnych (teoria dedukcyjna) i nauk przyrodniczych $^{19}$. Przyjmuje się tu, że rozwinięta teoria naukowa po-

18 Stopień zaawansowania systematyzujących wiedzę struktur językowych jest różny, co pokazuje m.in. możliwe rozróżnienie między koncepcją a teoria, por. (Walczak 2016).

${ }_{19} \mathrm{~W}$ metodologii nauk przyrodniczych teoria naukowa jest rozumiana już to zdaniowo (Rudolf Carnap, Carl Gustav Hempel) jako częściowo zinterpretowany system aksjomatyczny, już to teoriomodelowo (P. Sneed) jako struktura pojęciowa, przybierająca w fizyce postać równań matematycznych, por. (Ladyman 2005, s. 413, 416; Winther 2016). 
winna przybierać postać systemu dedukcyjnego albo do niego zbliżoną. Budowane w naukach formalnych (logice formalnej i matematyce) teorie (systemy dedukcyjne) uważane są za wzorcowe również w naukach przyrodniczych i generalnie, w naukach empirycznych (Grobler 2006, s. 139). W naukach empirycznych tradycyjne rozumienie teorii naukowej definiuje ją jako uporządkowany zbiór (system, układ) logicznie i rzeczowo powiązanych tez, tzn. najogólniejszych (zasad) i ogólnych hipotez, praw i definicji, które teoretycznie wyjaśniają wskazaną jednoznacznie dziedzinę rzeczywistości (zjawisk, faktów) (Kamiński 1992, s. 214). W teorii naukowej odróżnia się jej warstwę teoretyczną (tj. terminy i twierdzenia teoretyczne) od empirii jako warstwy empirycznej (empirycznych terminów i twierdzeń). Ze względu na swą funkcję wyjaśniającą (odpowiedź na pytanie „dlaczego?”), teorie naukowe uważa się za najbardziej poznawczo zaawansowane jednostki nauki. Tak maksymalistycznie rozumiane teorie naukowe zdarzają się jednak w nauce rzadko, kiedy zwyczajowo wymienia się mechanikę Newtona lub szczególną i ogólną teorię względności Einsteina.

Teoria naukowa uchodzi za poznawczo najbardziej dojrzałą strukturę wiedzy, odznaczającą się maksymalnym stopniem definiowania swych pojęć (terminów), uzasadniania twierdzeń (tez), ich logicznym uporządkowaniem (systematyzacją). Twierdzenia występujące $\mathrm{w}$ ramach teorii są odpowiedzią na precyzyjnie postawione i sformułowane pytania badawcze. Mogą one mieć różny stopień ogólności oraz różny charakter (być opisowe, wyjaśniające, wartościujące, normatywne). Teoria naukowa porządkuje maksymalnie i artykułuje uzasadnienia twierdzeń (argumenty na ich rzecz i przeciwko nim) oraz definiuje terminy (pojęcia) użyte do ich sformułowania. Tak scharakteryzowane pojęcie teorii może być stosowane w wielu dziedzinach. Spotykane w naukach humanistycznych i filozofii pojęcie teorii funkcjonuje w sposób ogólny (ogólnikowy) i mniej zreflektowany (Walczak 2016, s. 481-482).

\section{Język naukowy}

Z logiczną strukturą wiedzy naukowej, a także z uzasadniającymi (logicznymi) relacjami między twierdzeniami naukowymi wiąże się inny ważny determinant metodologicznego statusu nauki, jakim jest język naukowy. Standardowo tworzą go użyta aparatura pojęciowa (słownik) i reguły jej użycia: reguły konstrukcji i transformacji wyrażeń oraz reguły uznawania wyrażeń za prawdziwe i/lub wartościowe poznawczo. $\mathrm{Na}$ aparaturę pojęciową pewnej nauki (Ajdukiewicz 1985a) składają się jej kluczowe terminy, zróżnicowane na terminy empiryczne (obserwacyjne) 
i teoretyczne (centralne dla nauki), opisowe i wartościujące, klasyfikujące i typologiczne, nazwy generalne, indywidualne, konstrukty, idealizacje itp. Terminy tworzące aparaturę pojęciową danej nauki są równocześnie nazwami badanych przez nią przedmiotów i stąd determinują je językowo i współkonstruują.

Naukę, zarówno w postaci dyscypliny naukowej, typu nauk, jak i projektu badawczego, charakteryzują zwłaszcza przyjęte przez nie reguły uznawania zdań za prawdziwe i (lub) wartościowe poznawczo. Reguły uznawania zdań, widziane w kontekście teorii (sytemu zdań), w której są osadzone, nie ograniczają się jedynie do rozstrzygania o ich wartości logicznej, gdyż przy uznawaniu twierdzeń bierze się pod uwagę szereg cech i własności teorii, do której przynależa, jak adekwatność empiryczna, niesprzeczność, precyzja, moc wyjaśniająca i prognostyczna, prostota itp. (Kamiński 1992, s. 225; Dąbek 2018).

Jak pokazują konkretne realizacje języka naukowego, trudno mówić o istnieniu jednego języka naukowego spełniającego te same kryteria precyzji i sprawdzalności. Nie znaczy to jednak, że nie można pod jego adresem formułować ogólnego wymogu intersubiektywnej komunikowalności i uzasadnialności. Bogactwo opisywanych i wyjaśnianych aspektów rzeczywistości, a także różnorodność typów nauk sprawia, że istnieje wiele realizacji tego, co nazywa się językiem naukowym ${ }^{20}$. $Z$ tych samych powodów nie daje się zredukować języka wszystkich dyscyplin naukowych do języka jednego typu nauki, np. fizyki (Kamiński 1992, s. 278).

\section{Geneza i dzieje nauki}

Rzadziej wymienianym determinantem metodologicznego statusu nauki lub jej statusu instytucjonalno-społecznego są jej geneza i dzieje (dynamika, historia). Tymczasem odpowiedź na pytanie, jak powstała i jak się rozwijała pewna nauka, okazuje się ważna nie tylko dla zrozumienia jej dziejów. Odgrywają one również istotną rolę zwłaszcza w tych naukach, w których rozwój nie polega na samym przezwyciężaniu starych koncepcji przez nowe (jak w fizyce czy biologii), lecz na podejmowaniu stałych (tych samych?) pytań w coraz to nowszym i zmieniającym się kontekście historycznym oraz na badaniu odpowiedzi na nie, jakie były formułowane $\mathrm{w}$ toku ich rozwoju na przestrzeni wieków (jak to ma miejsce w filozofii czy naukach humanistycznych). Zrozumienie podejmowanych problemów, głoszonych tez, a także używanych pojęć niejednokrotnie zależy od znajomości ich dziejów. Dodatkowo historia nauk może przyczyniać się do integracji wiedzy, ponieważ uwzględnienie w badaniach

${ }^{20}$ Np. o specyfice języka nauk humanistycznych por. (Pelc 2000). 
genezy podejmowanych problemów i zdawanie sobie sprawy z powstania, rozwoju i powiązań interdyscyplinarnych problematyki, nad którą się pracuje, może ułatwiać badania interdyscyplinarne (Kamiński 1992, s. 278-279).

Dzieje nauki to także problem jej dynamiki, rozumiany jako zagadnienie zmian i (lub) rozwoju (postępu) w nauce. Jest on centralny, gdyż z jednej strony wyznacza model rozumienia zmian w nauce: kumulatywny, ewolucyjny lub rewolucyjny (akumulatywny), a z drugiej sposobu traktowania wiedzy naukowej w przeszłości: odrzucenie, akceptacja lub kontynuacja $^{21}$. Kluczowe dla ujęcia metodologicznego statusu nauki okazuje się też jej zrozumienie jako procesu twórczego i odkrywczego, nastawionego na dodanie do istniejącego zasobu wiedzy ludzkości na danym etapie historycznym czegoś relatywnie nowego lub na przezwyciężenie i radykalną zmianę aktualnego stanu wiedzy (Kamiński 1992, s. 225-230).

\section{Status metodologiczny a status instytucjonalno- -społeczny nauki}

Chociaż kategoria statusu metodologicznego nauki pozwala na całościową charakterystykę metodologiczną nauki oraz jej podstawowych jednostek (jak dyscypliny naukowe czy projekty badawcze), nie dostarcza ona opisu nauki w innych aspektach niż epistemiczny i formalny. Warto dla bardziej całościowej charakterystyki nauki wziąć pod uwagę także takie rodzaje statusu nauki, jak jej status instytucjonalno-społeczny. Chociaż charakterystyki nauki oznaczane przez kategorie statusu metodologicznego i instytucjonalno-społecznego nauki wzajemnie się uzupełniają i w praktyce nauki wzajemnie na siebie wpływają (Kawalec 2019), nie powinno się ich mieszać, jeżeli chce się zachować specyfikę idealizującego, metodologicznego podejścia do nauki, gdyż wyznaczają je inne determinanty i inaczej w ich ramach pojmuje się naukę. Status instytucjonalno-społeczny nauki ujmuje naukę jako dziedzinę kultury i instytucję społeczną ze względu na takie determinanty, jak: nazewnictwo dyscypliny lub dziedziny nauki; instytucje (katedry, instytuty, szkoły, uniwersytety, ośrodki badawcze, towarzystwa naukowe, konferencje); regulacje prawne, a także prestiż społeczny, jakim cieszy się dana nauka (świadomościowy odbiór nauki); twórcy, klasycy, główne postacie; wspólnoty badawcze, środowiska naukowe, szkoły, tradycje; geneza/dzieje/dynamika (krzyżująca się tu z wyznacznikami statusu metodologicznego ${ }^{22}$.

${ }^{21}$ Na ten temat por. (Hajduk 1995; Kawalec 2019).

22 Na takie wyznaczniki zwraca uwage już Kotarbiński (1990, s. 334-335). 


\section{Bibliografia}

Ajdukiewicz K. [1965] (1975), Logika pragmatyczna, PWN, Warszawa.

Ajdukiewicz K. (1985) Metodologia i metanauka, [w:] idem, Język i poznanie, t. 2, PWN, Warszawa, s. 117-126.

Ajdukiewicz K. (1985a), Obraz świata i aparatura pojęciowa, [w:] idem, Język i poznanie, t. 1, PWN, Warszawa, s. 175-195.

Bronk A. (2001), Wykłady do postuchania. Grudzień 2001, http://www.kul.pl/wyklady-audio,12136.html (dostęp: 21.07.2019).

Bronk A. (2003), Czy pedagogika jest nauka autonomiczną?, [w:] M. Nowak. T. Ożóg. A. Rynio (red.), W trosce o integralne wychowanie, Wydawnictwo KUL, Lublin, s. 46-76.

Bronk A., Majdański S. (1995), Kategoria opisu: dynamika znaczeń (analiza hermeneutyczna), „Roczniki Filozoficzne” 43, 1, s. 5-39.

Brożek A. (2007), Pytania i odpowiedzi. Tło filozoficzne, teoria i zastosowania praktyczne, Wydawnictwo Naukowe Semper, Warszawa.

Czeżowski T. (1958), Odczyty filozoficzne, Towarzystwo Naukowe w Toruniu, Toruń.

Czeżowski T. (1965), Filozofia na rozdrożu. Analizy metodologiczne, PWN, Warszawa.

Czeżowski T. (1967) O jedności nauki, [w:] T. Czeżowski (red.), Fragmenty filozoficzne. Seria III. Księga Pamiątkowa ku czci profesora Tadeusza Kotarbińskiego w osiemdziesiata rocznice urodzin, PWN, Warszawa, s. 17-28.

Dąbek D. (2018), Pozaempiryczne kryteria oceny teorii w kosmologicznej praktyce badawczej, Wydawnictwo KUL, Lublin.

Grobler A. (2006), Metodologia nauk, Wydawnictwo Aureus, Wydawnictwo Znak, Kraków.

Hajduk Z. (1995), Temporalność nauki. Kontrowersyjne zagadnienia dynamiki nauki, Wydawnictwo KUL, Lublin.

Hajduk Z. (2007), Ogólna metodologia nauk, wyd. 4 zm., Wydawnictwo KUL, Lublin.

Hajduk Z. (2012), Ogólna metodologia nauk, wyd. 6 uzup., Wydawnictwo KUL, Lublin.

Kamiński S. (1961), Pojęcie nauki i klasyfikacja nauk, wyd. 1, Towarzystwo Naukowe KUL, Lublin.

Kamiński S. (1992), Nauka i metoda. Pojęcie nauki i klasyfikacja nauk. Pisma wybrane, t. 4, wyd. 4, Towarzystwo Naukowe KUL, Lublin.

Kawalec P. (2019), Metodologia integralna. Studium dynamiki wiedzy naukowej, Wydawnictwo KUL, Lublin.

Kotarbiński T. (1990), Elementy teorii poznania, logiki formalnej i metodologii nauk, Wydawnictwo Ossolineum, Lwów, Wrocław.

Kotarbiński T. (1990a), O pojęciu metody, „Zeszyty Wydziału Filozoficznego Uniwersytetu Warszawskiego" 1957, 1; przedruk w: J. Woleński, Kotarbiński, Wiedza Powszechna, Warszawa, s. 183-196.

Ladyman J. (2005), Theories and Theoretical Terms, [w:] D.M. Borchert (red.), The Encyclopedia of Philosophy, t. 9, Thomson and Gale, New York-London, s. 413-418.

Lekka-Kowalik A. (2008), Odkrywanie aksjologicznego wymiaru nauki, Wydawnictwo KUL, Lublin.

Pelc J. (2000), Myśli o języku humanistyki, [w:] J. Pelc (red.), Język współczesnej humanistyki, Polskie Towarzystwo Semiotyczne, Warszawa, s. 171-204.

Podsiad A., Więckowski Z. (red.) (1983), Mały słownik terminów i pojęć filozoficznych dla studiujacych filozofię chrześcijańska, Instytut Wydawniczy PAX, Warszawa.

Repko A., (2008), Interdisciplinary Research: Process and Theory, Sage, Los Angeles. 
Sankey H. (2008), Scientific Method, [w:] M. Curd, S. Psillos (red.), The Routledge Companion to Philosophy of Science (2014), wyd. 2, Routledge, London-New York, s. 280-290.

Status, http://synonim.net/synonim/status (dostęp: 4.12.2017).

Twardowski K. (1965), O naukach apriorycznych, czyli racjonalnych (dedukcyjnych), i naukach aposteriorycznych, czyli empirycznych (indukcyjnych), [w:] idem, Wybrane pisma filozoficzne, PWN, Warszawa, s. 364-372.

Walczak M. (2011), Stanisława Kamińskiego poglady na cel nauki, „Zagadnienia Naukoznawstwa" 3, s. 391-405.

Walczak M. (2016), O różnicy między tematem a problemem badawczym, [w:] M. Tkaczyk, M. Krupa, K. Jaworski (red.), Veritas in caritate. Ksiegga pamiatkowa ku czci Księdza Profesora Andrzeja Szostka, Wydawnictwo KUL, Lublin, s. 497-502.

Winther R.G. (2019), The Structure of Scientific Theories, [w:] E.N. Zalta (red.), Stanford Encyclopedia of Philosophy (Winter 2016 Edition), https://plato.stanford.edu/archives/ win2016/entries/structure-scientific-theories (data dostępu: 30.12.2019).

\section{Streszczenie: Kategoria statusu metodologicznego nauki}

Celem artykułu jest utrwalenie i doprecyzowanie znaczenia terminu „status metodologiczny nauki", a tym samym wzmocnienie samoświadomości metodologicznej naukowców, metodologów i filozofów nauki. Prezentowane rozważania służą autorefleksji, gdyż omówione tu kategorie stosują się również do metodologii i filozofii nauki. Pojęcie statusu metodologicznego jest najogólniejszą kategoria, pozwalającą adekwatnie scharakteryzować od strony formalnej naukę w ogóle i poszczególne dyscypliny naukowe. Chociaż używane przez wielu, kiedy zwracają oni uwagę na wyznaczniki statusu nauki (przedmiot badań, cel badawczy, problematykę badawcza, metodę badań, strukturę wiedzy, język naukowy, genezę i dzieje nauki), nie doczekało się dokładniejszego określenia, doprecyzowującego jego znaczenie oraz sens konstytuujących je wyznaczników. W prezentowanym tekście chciałabym ten brak nadrobić.

Słowa kluczowe: nauka, badania, status metodologiczny nauki, metodologia nauk, filozofia nauki

Summary: On the Category of Methodological Status of Science

The aim of my paper is to consolidate and clarify the meaning of the term methodological status of science and thus increase the methodological self-consciousness of scientists, methodologists and philosophers of science. The present considerations serve the purpose of self-reflection, because the categories in question apply also to the methodology and philosophy of science. The notion of methodological status is the most general category by means of which it is possible to characterize science in general, and particular scientific disciplines in a formal terms. Although used by many authors, when drawing attention to the determinants 
of the status of science (the object of research, research objective, research problems, research method, structure of knowledge, scientific language, genesis and history of science), it has not been defined precisely yet, as regards specification of its meaning and the meaning of the determinants that constitute it. In my text I would like to fill in the gap.

Keywords: science, research, methodological status of science, methodology of science, philosophy of science 